\title{
A Longitudinal Study on the Natural Infection of Biomphalaria straminea and B. glabrata by Schistosoma mansoni in an Endemic Area of Schistosomiasis in Pernambuco, Brazil
}

\author{
Tereza C Favre/ ${ }^{+}$, Otávio S Pieri, Luciana C Zani, Jainne M Ferreira, Glauce G Domás, \\ Lilian H Beck, Constança S Barbosa*
}

\author{
Departamento de Biologia, Instituto Oswaldo Cruz-Fiocruz, Av. Brasil 4365, 21045-900 Rio de Janeiro, RJ, Brasil \\ *Departamento de Parasitologia, Centro de Pesquisas Aggeu Magalhães-Fiocruz, Recife, PE, Brasil
}

\begin{abstract}
The abundance of snail hosts and the rates of infection with Schistosoma mansoni were monitored monthly for four years in two representative localities subjected to repeated chemotherapy of infected persons. Snail abundance varied from 1.0 to 4.4 collected per person/minute/station for Biomphalaria straminea and from 0.1 to 7.0 for $\mathrm{B}$. glabrata. Infection rates of snails in nature varied from $0 \%$ to $15 \%$ for the former and from $0 \%$ to $70 \%$ for the latter species. Human infection increased from $35.5 \%$ to $61.9 \%$ in the locality occupied by B. straminea, and decreased from $40.3 \%$ to $20.8 \%$ in that occupied by B. glabrata. No relationship could be detected between human infection and the snail variables. Despite seasonal variations, natural infection persisted throughout the monitoring period in both snail species. It reached remarkably high levels in B. straminea when compared to those obtained by other authors probably because of differences in methodology. It is recommended that longitudinal studies should be carried out focally and periodically to avoid underestimating the prevalence of schistosome infection in snails.
\end{abstract}

Key words: Biomphalaria straminea - Biomphalaria glabrata - Schistosoma mansoni - natural infection - longitudinal study Pernambuco - Brazil

In the Brazilian state of Pernambuco, schistosomiasis exhibits an epidemiological profile of chronic infection and persistent reinfection in the rainforest area (Zona da Mata). Heavy infections are also frequent in the coastal area (Barbosa et al. 2000, 2001). Despite the amount of data amassed over the years and the advances in immunological and therapeutic clinical research, control of schistosomiasis transmission still represents a challenge for government institutions (Barbosa \& Coimbra 2000). Although morbidity indices remain low, the prevalence of infection and the rate of reinfection have remained high in rural areas despite repeated treatment with oxamniquine (Pieri et al. 1998, Favre 1999).

Longitudinal studies of infected snails in critical areas, in parallel with application of control measures may shed light on why control measures fail. Nevertheless, few have been carried out (Dazo et al. 1976, Gundersen et al. 1990).

In Pernambuco, there are two intermediate host species of Schistosoma mansoni: Biomphalaria straminea and $B$. glabrata. The first species is widespread over the Agreste, a zone of transitional vegetation, and the Zona da Mata, where it maintains high endemicity levels despite the low rates of natural and experimental infection (Paraense \& Corrêa 1989). The second species, with infection rates reaching up to $20 \%$, is mainly found in coastal

${ }^{+}$Corresponding author. Fax: +55-21-2560.6474. E-mail: tfavre@ioc.fiocruz.br

Received 6 June 2001

Accepted 17 April 2002 areas, and remains responsible for several active foci of transmission (Barbosa et al. 2000).

The present study aims to assess, on a monthly basis over a period of four years, the relative abundance and the natural infection of $B$. straminea and B. glabrata by $S$. mansoni in two representative localities in an endemic area in the state of Pernambuco, where infected persons were treated periodically with oxamniquine. In addition, tests were carried out to ascertain the susceptibility of snail species found in these localities to local parasite strains.

\section{MATERIALS AND METHODS}

Two rural localities sharing similar sociodemographic characteristics and displaying medium levels of endemicity in relation to schistosomiasis (prevalence ranging from $30 \%$ to $40 \%$ ), populated by distinct intermediate host species, were chosen after a preliminary stool survey and the application of a home questionnaire as described by Moza et al. (1998). Nine stool surveys by the Kato-Katz method (Katz et al. 1972) were undertaken every three months in both localities and individuals who tested positive for S. mansoni were treated with oxamniquine (Pieri et al. 1998), in March 1995, June 1995, March 1997 and March 1998.

Characterization of the study area - Ecological features relevant to schistosomiasis transmission were recorded, including water-contact habits and rainfall. As recommended by Olivier (1973), sketch maps were used to display the location of houses, land use and water resources of each locality.

Malacological survey - Snail breeding sites regarded as potential of transmission foci were identified in both localities. Snails were collected monthly from predetermined stations over the four years of the follow-up sur- 
vey (January 1995 - December 1998). In order to estimate the relative abundance of the two snail host species in the breeding places, snails were collected according to the Olivier and Schneiderman (1956) method.

Natural infection survey - Groups consisting of up to 100 snails were collected monthly, from each station, and then sent to a laboratory where they were placed in a room with a light cycle of $12 \mathrm{~h}$ light and $12 \mathrm{~h}$ dark, at temperatures ranging from $25^{\circ} \mathrm{C}$ to $28^{\circ} \mathrm{C}$. They were kept in glass containers with 41 of non-chlorinated water and fresh lettuce. Screening for the identification of positive snails was carried out at weekly intervals, over a period of one month (Favre et al. 1995). The containers were inspected twice a day to detect snails with signs of distress or imminent death. Such snails as well as those that remained alive after the last screening were crushed so as to allow for the search for larval stages of S. mansoni (Olivier 1973). As these might be indistinguishable from those of other trematode species in the earlier stages in the snail, only recognizable schistosome infections were considered. Two indicators related to the natural infection of each host species were estimated monthly: (a) global infection - proportion of examined snails hosting sporocysts and/or cercariae of $S$. mansoni in all collecting stations for each locality, and (b) focal infection - proportion of examined snails hosting sporocysts and/or cercariae of $S$. mansoni, in each collecting station that contained naturally infected snails at least once during the survey.

Experimental susceptibility test - In order to determine rates of $B$. straminea and $B$. glabrata experimental infection by $S$. mansoni, strains of the parasite were isolated from naturally infected snails from each locality. Therefore, 500 specimens of each snail species were individually exposed to the parasite load of 5 miracidia; 250 of them to the syntopic strain (from the same locality), while the other 250, to the alotopic strain (from the other locality) of S. mansoni. Screening for the identification of positive snails was performed thrice weekly (Favre et al. 1995). Snails that were still alive after 70 days of miracidium exposure and that did not produce cercariae during the screenings, were crushed for the search for S. mansoni larval stages.

Statistical analysis of data - Significant associations $(p<0.05)$ between relative abundance and rainfall, relative abundance and natural infection, as well as between rainfall and natural infection were analysed for each snail species through the Spearman correlation coefficient $\left(r_{s}\right)$, by matching the collected data throughout the 48 months of the study. Significant differences $(p<0.05)$ of relative abundance and natural infection between the two species were made with the use of the Wilcoxon test, by matching the data along the 48 months of collection. Experimental infection rates of the two species were compared by means of $2 \times 2$ contingency tables, using the chi-square $\left(\chi^{2}\right)$ test, or Fisher's exact test (Sokal \& Rohlf 1995).

\section{RESULTS}

Characterization of the localities chosen for study Corte de Camorim ( $37^{\circ} 04^{\prime} \mathrm{W}$; $\left.07^{\circ} 58^{\prime} \mathrm{S}\right)$ is a small rural vil- lage, $5 \mathrm{~km}$ away from the town of São Lourenço da Mata, in the region physiographically known as Zona da Mata (Fig. 1). Land occupation is characterized by sugar-cane plantation. On its irregular terrain, 111 houses are distributed along a railroad. Most of these houses are mud huts without cesspits. The main water source in the area is the Imbaúba stream, a seasonally drying tributary of the Capibaribe river, that runs parallel to the railroad across the whole village. The river is used by the population for leisure activities, bathing and household chores. Superficial wells drilled into the ground water plate (cacimbas), are used by families as the only water resource for drinking and cooking. Despite the seasonal characteristics of the Imbaúba stream, some streches retain water in isolated pools even during the dry season (August-February). These pools and others surrounding the cacimbas proved to be favorable habitats for $B$. straminea, the only snail host species in this locality. In all, 14 snail collecting stations were located in Corte do Camorim, 10 of them along the stream and four cacimbas (Fig. 1).

Bom Jesus ( $\left.34^{\circ} 49^{\prime} \mathrm{W} ; 07^{\circ} 46^{\prime} \mathrm{S}\right)$ is a site located $3 \mathrm{~km}$ away from the urban center of Itamaracá, a coastal municipality where land occupation is for subsistence only (Fig. 2). There are 62 brick houses in the area: some are distributed along the main road, and the others are scattered across the area. Most houses have cesspits although many are badly maintained thus allowing leakage of faecal matter in the residential area. As the gradient is gentle the lower areas are permanently flooded during the rainy season thus constituting excellent breeding places for B. glabrata, the local snail host species. Two main streams cross the area. Stream 1 is perennial and its source lies in the higher part of the terrain, forming small pools along its course. These pools are used by locals for domestic activities including bathing and leisure. Stream 2 is formed by natural rainwater impounding, and remains dry during most part of the year. The area around this stream is an important pathway for the local population. During the rainy season (March-August), this area is flooded and becomes a large marsh where B. glabrata proliferates. A total of 12 collecting stations were demarcated in Bom Jesus, 11 of them along stream 1, and one in stream 2 (Fig. 2).

Relative abundance - The abundance of $B$. straminea in the breeding places in Camorim varied from 0.1 (February, April and August 1998) to 4.4 snails per person/minute/ station (February 1995 and February 1997) (Fig. 3A). Throughout the 48 monthly collections, B. straminea snails were not found on only two occasions (March and July 1998). There was no significant correlation between this variable and rainfall $\left(r_{s}=0.055 ; p>0.05 ; n=48\right)$. The abundance of $B$. glabrata in the breeding places in Bom Jesus varied from 0.1 (April and May 1995 and March 1996) to 7.0 snails per person/minute/station (August 1997) (Fig. 4A). B. glabrata snails were not found in only two of 48 monthly collections (October 1997 and March 1998). No significant correlation was found between the abundance of $B$. glabrata in its breeding places and rainfall $\left(\mathrm{r}_{\mathrm{s}}=0.085 ; \mathrm{p}>0.05 ; \mathrm{n}=48\right)$.

Natural infection - A total of $14,774 \mathrm{~B}$. straminea snails were examined, of which only $53(0.4 \%)$ were found in- 
fected with S. mansoni. Of these, 9 were recognized as such through cercarial shedding. The remaning 44 snails were recognized through crushing, as they harboured secondary sporocysts, mainly in the digestive gland and ovotestis. A total of $6,826 \mathrm{~B}$. glabrata snails were examined, $285(4.2 \%)$ of which were found infected with S. mansoni. Of these, 193 shed cercariae and the remaining 92 harboured secondary sporocysts, mainly in the digestive gland and ovotestis. Thirty-five $(0.2 \%)$ B. straminea snails and $21(0.3 \%)$ B. glabrata snails were found infected with other trematode species. However, no snail was found concomitantly infected with $S$. mansoni and other trematode species.
Rates of global infection of $B$. straminea, from January 1995 to December 1998, varied from 0 to $4.3 \%$ (Fig. $3 \mathrm{~B}$ ). During the months the snails tested positive the lowest infection rate was $0.1 \%$ (March 1995). The presence of naturally infected snails was recorded in only $18(37.5 \%)$ of the 48 months of survey. Half (9) of these cases occurred during rainy months and the other half during the dry months, when abundance varied from 0.3 to 4.4 snails per person/minute/station. The rate of global infection of B. glabrata between January 1995 and December 1998, varied from $0 \%$ to $52 \%$ (Fig. 4B). In those months snails tested positive, the lowest infection rate was $0.5 \%$ (April 1996, June and July 1998). During the 48 months of snail

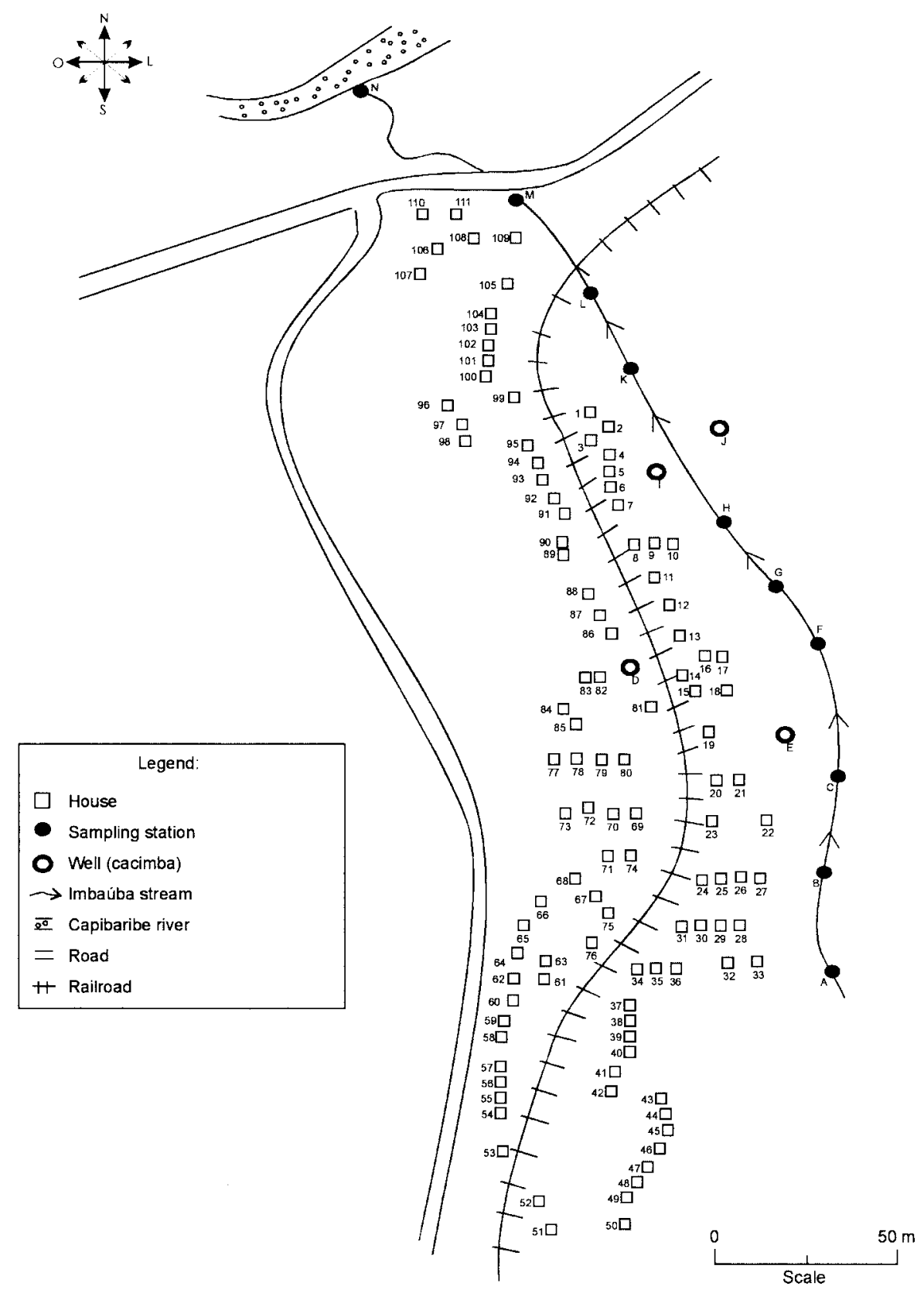

Fig. 1: schematic representation of the main hydrographic, topographic and housing conditions of the locality of Corte de Camorim $\left(37^{\circ} 04^{\prime} \mathrm{W} ; 07^{\circ} 58^{\prime} \mathrm{S}\right), 5 \mathrm{~km}$ away from the seat of the municipality of São Lourenço da Mata, PE, Brazil. 
collection, naturally infected $B$. glabrata snails were found in 36 months $(75 \%), 20$ of these $(55.6 \%)$ constituted the dry season and $16(44.4 \%)$, the rainy season. The highest rates of global infection registered for B. glabrata was 52\% (September 1997), 13.4\% (February 1996) and 13.3\% (August 1995).

There was no significant correlation between the infection of B. straminea and rainfall $\left(\mathrm{r}_{\mathrm{s}}=0.129 ; \mathrm{p}>0.05 ; \mathrm{n}\right.$ $=48$ ). On the other hand, there was a significantly positive correlation between the percentage of natural infection and the abundance of such species in its breeding places $\left(r_{s}=0.295 ; p<0.05 ; n=48\right)$. In fact, the presence of infected B. straminea snails, in general, coincided with the months in which they were more abundant in the breeding places. It is noteworthy that the third most abundant occurrence of B. straminea (May 1998) coincided with the only month in that year when infected snails were found.

There was no significant correlation between the infection of B. glabrata and rainfall $\left(\mathrm{r}_{\mathrm{s}}=0.120 ; \mathrm{p}>0.05 ; \mathrm{n}=\right.$ 48) throughout the 48 months of snail collection, although most cases of naturally infected B. glabrata occurred during the dry months, when infection rates reached their highest. The highest rates of infection of this snail spe-

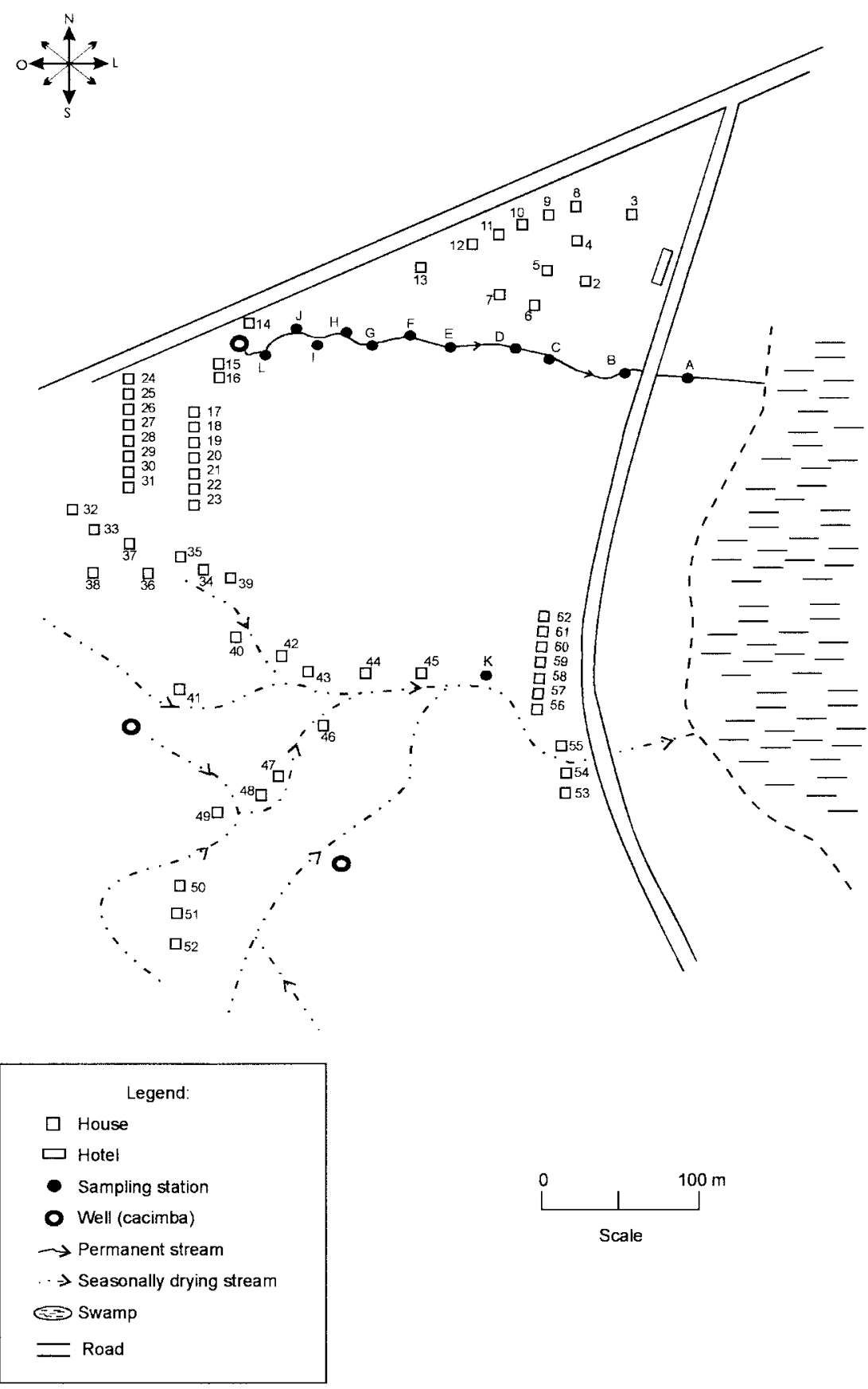

Fig. 2: schematic representation of the main hydrographic, topographic and housing conditions of the locality of Bom Jesus ( $34^{\circ} 49^{\prime} \mathrm{W}$; $\left.07^{\circ} 46^{\prime} \mathrm{S}\right), 2 \mathrm{~km}$ away from the seat of the municipality of Itamaracá, Pernambuco, PE, Brazil. 


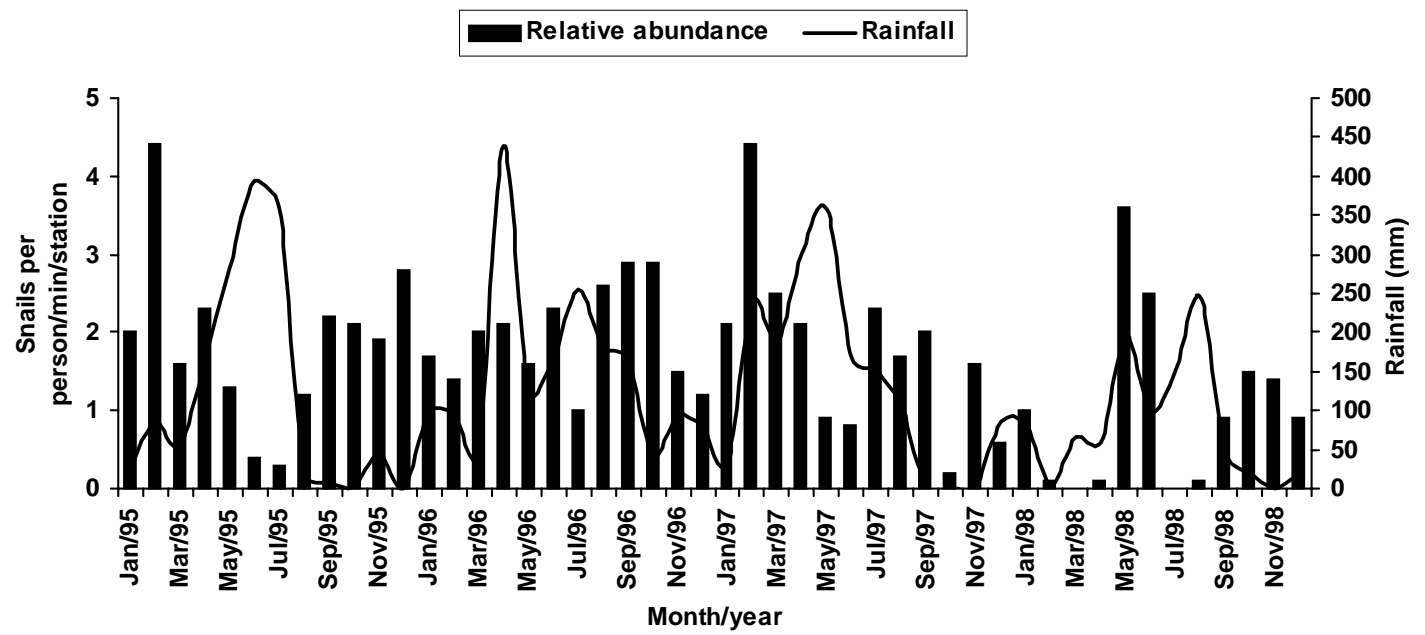

B

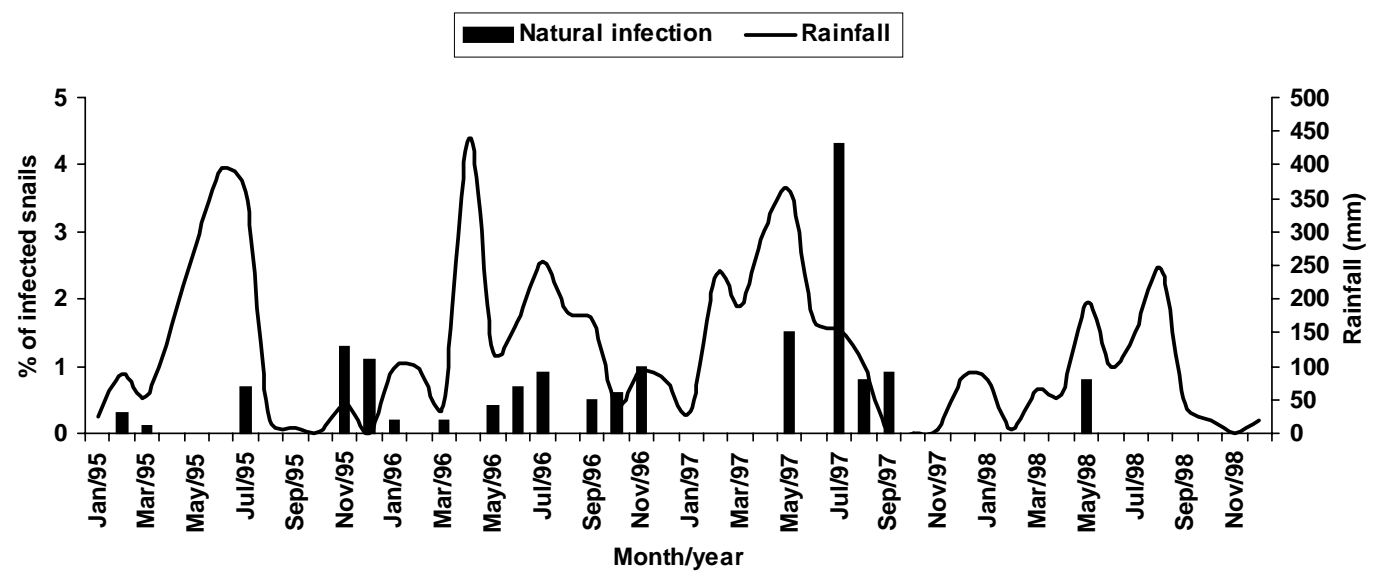

Fig. 3: seasonal changes in abundance of Biomphalaria straminea (A), in the percentages of snails infected with Schistosoma mansoni (B) and rainfall, during the four years of monthly survey, from January 1995 to December 1998, in the snail habitats in Corte de Camorim, São Lourenço da Mata, PE, Brazil.

cies were registered during the months of lowest abundance of snails in their breeding places $(<2$ snails per person/minute/station). However, there was no significant correlation between natural infection and the abundance of $B$. glabrata in the breeding places $\left(\mathrm{r}_{\mathrm{s}}=0.228 ; \mathrm{p}\right.$ $>0.05 ; \mathrm{n}=48$ ).

Table I shows the rates of focal infection of B. straminea in Corte do Carmorim. In 11 (78.6\%) of the 14 collecting stations snails were infected in at least one occasion. In these 11 collecting stations, rates of focal infection varied from $0.6 \%$ (station F, July 1996) to $14.7 \%$ (station M, November 1995) and, therefore, were higher than the rates of global infection estimated for the species. The months with larger numbers of collecting stations having infected B. straminea snails were July 1997 (5 stations), December 1995 (4 stations) and June 1996 (3 stations).

Table II shows the focal infection of B. glabrata, in Bom Jesus. In 5 (41.7\%) of the 12 collecting stations snails were infected in at least one occasion. In these 5 collecting stations, rates of focal infection varied from $0.8 \%$ (station K, July 1995) to $70 \%$ (station B, July 1996). The latter was higher than the rates of global infection estimated for this snail host species. In 26 occasions infected $B$. glabrata were found in only one station.

No significant difference was found between the relative abundance of $B$. straminea in Corte do Camorim and that of B. glabrata $(Z=-0.475 ; p>0.05)$ in Bom Jesus. However, rates of natural infection estimated for $B$. glabrata were significantly higher than those estimated for $B$. straminea $(\mathrm{Z}=4.927$; $\mathrm{p}<0.001)$.

Variables related to schistosomiasis - Table III gives the results from a home questionnaire and a preliminary stool survey carried out on schistosomiasis in Corte de Camorim and Bom Jesus in March 1995. Epidemiological, socioeconomic and sanitary conditions in both localities were similar, the only noticeable difference being the species of $S$. mansoni host snail. 
A

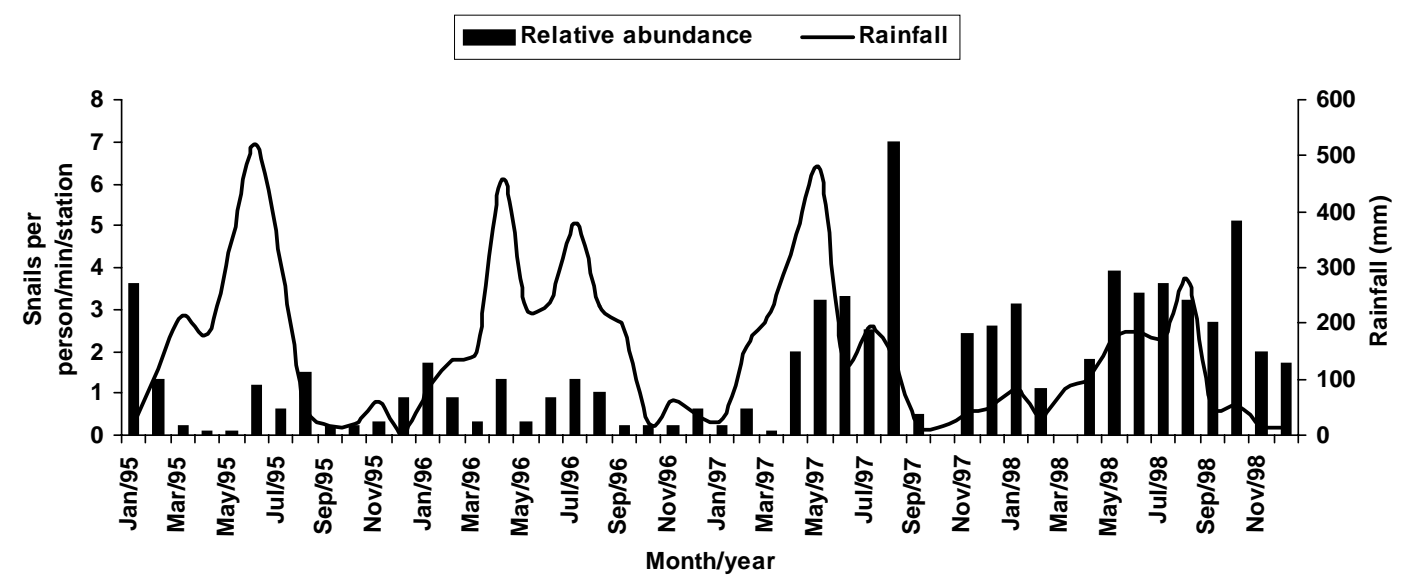

B

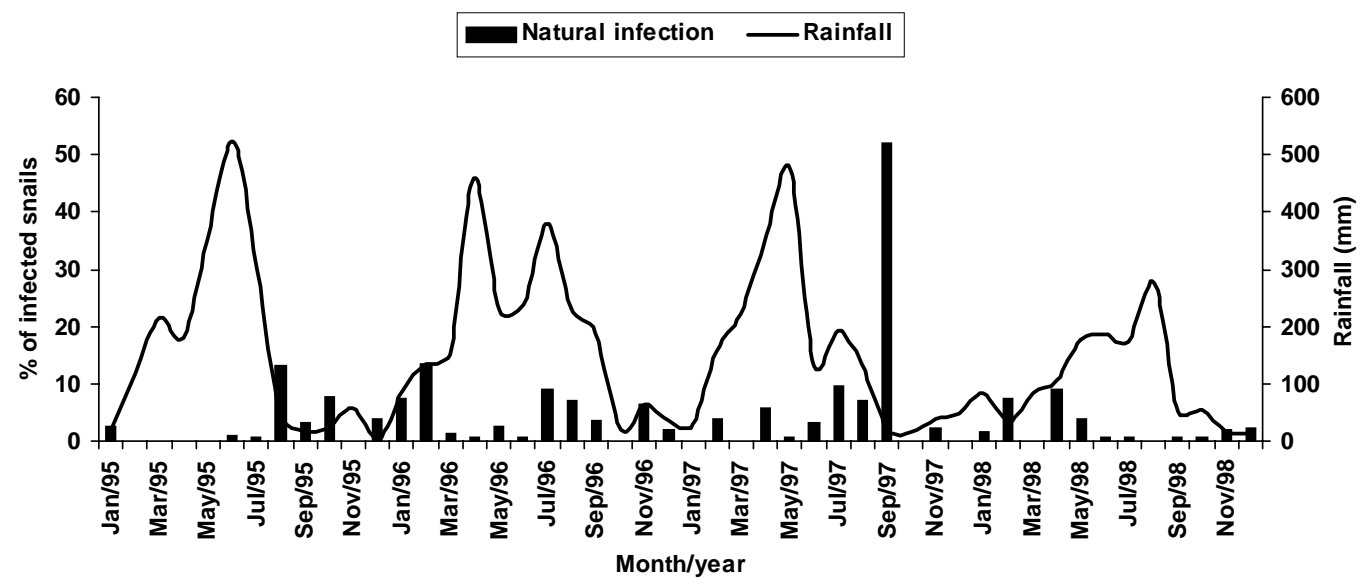

Fig. 4: seasonal changes in abundance of Biomphalaria glabrata (A), in the percentages of snails infected with Schistosoma mansoni (B) and rainfall, during the four years of monthly survey, from January 1995 to December 1998, in the snail habitats Bom Jesus, Itamaracá, PE, Brazil.

Results with respect to human infection and chemotherapy in the study areas will be presented in detail in another paper. Table IV only displays the yearly data on human infection before each cycle of treatment. In Corte de Camorim the prevalence of infection [\% with eggs per gram of feaces (epg) $>0$ ] remained above $25 \%$ in all the surveys and, in March/98, both the prevalence of infection and that of moderate to heavy infections (\% with epg $>100$ ) continued to increase despite repeated treatments. In contrast, in Bom Jesus, these two indices decreased after treatment.

Experimental infection of S. mansoni - Table V displays infection rates obtained for $B$. straminea and B. glabrata after experimental infection with syntopic and alotopic strains of $S$. mansoni. The rate of experimental infection for B. glabrata was notably higher than the one reported for $B$. straminea, in relation to both strain of S. mansoni: syntopic $\left(\chi^{2}=125.78 ; \mathrm{p}<0.05\right)$ and alotopic $\left(\chi^{2}=26.06 ; \mathrm{p}<0.05\right)$. There was no significant difference between experimental infection rates of $B$. straminea with syntopic and alotopic strains ( $\mathrm{p}>0.05)$, but the rate of infection of B. glabrata with the syntopic strain was notably higher than the one registered with the alotopic strain $\left(\chi^{2}=49.38 ; p<0.05\right)$.

\section{DISCUSSION}

There was a great deal of variation in the abundance of B. straminea in Corte do Camorim and of B. glabrata in Bom Jesus, and the percentages of snails infected with S. mansoni varied substantially during the two years following treatment of the infected persons carried out in March and June 1995. However there were no marked seasonal trends. Although there was no significant relationship between these variables and the indices of human infection, transmission continued during most of the 4 years of observation in both localities of the study (Figs 3B, 4B). These results are in accord with those of Barbosa and Coelho (1956) in the same endemic area. 
Table VI shows the populational density and natural infection of the two snail host species, as well as rainfall, in the localities being surveyed. Based on Barbosa (1962), three climatic seasons were identified: "winter" (AprilJuly), "post-winter" (August-November) and "summer" (December-March). There is no significant variation either in relative abundance or in natural infection among the 3 seasons. These findings are in contrast with those by Barbosa (1962) as he found that snail infection tended to reach zero during the summer. The present study, however, reports the occurrence of natural infection, even during the summer, in both snail species. Such a difference can be accounted for by the fact that habitats described by Barbosa remained dry from December to March,

\section{TABLE I}

Prevalence (\%) of Schistosoma mansoni in Biomphalaria straminea measured at monthly intervals over four years in each collecting station that contained infected snails in Corte do Camorim

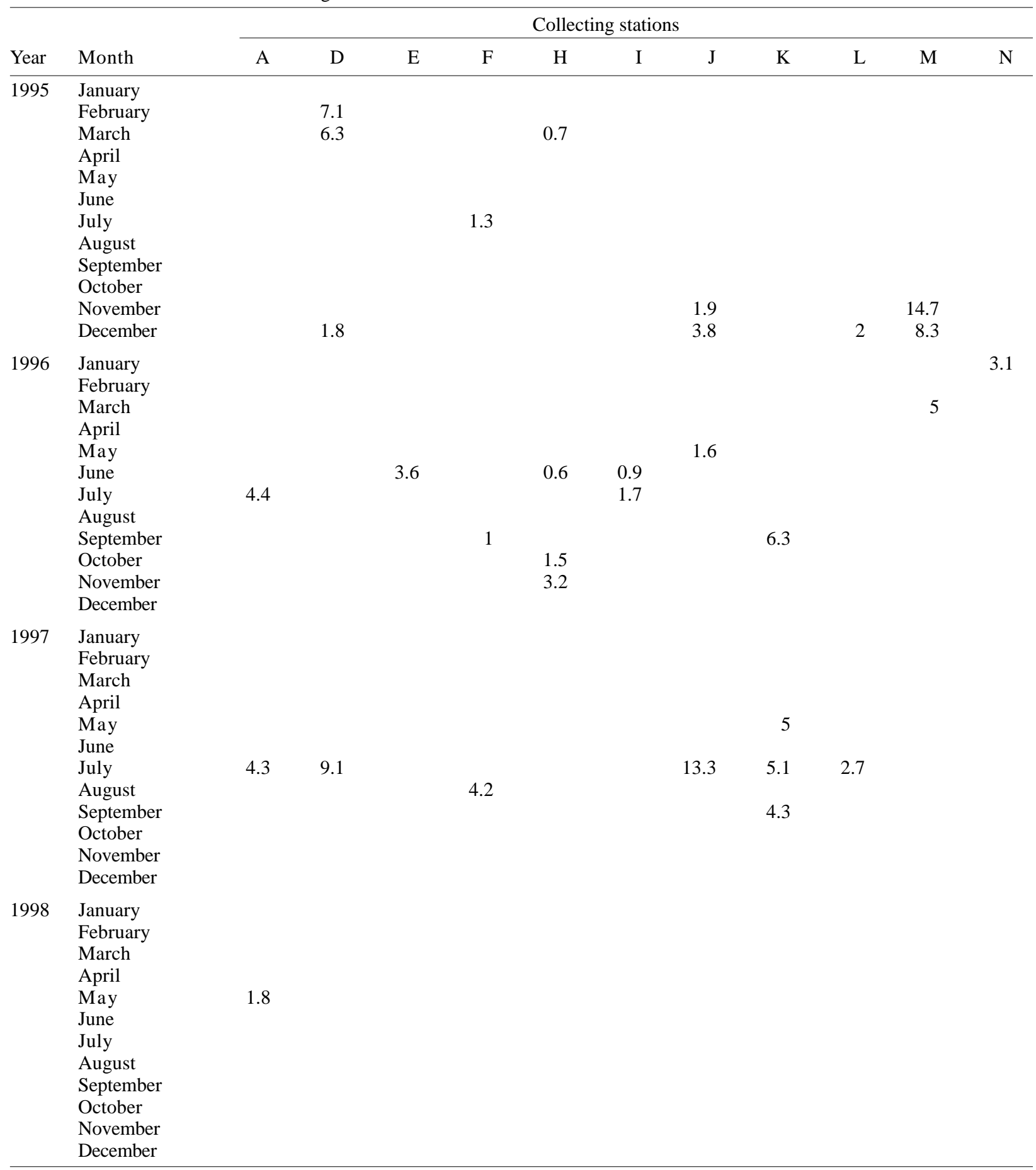


whereas in both localities of the present study, breeding places retained some water, although at very low levels, even in the summer.

It is noteworthy that, between May and September 1997, the rate of focal infection for $B$. straminea in Corte do Camorim was relatively high, reaching $13.3 \%$. This might

\section{TABLE II}

Prevalence (\%) of Schistosoma mansoni in Biomphalaria glabrata measured at monthly intervals over four years in each collecting station that contained infected snails in Bom Jesus, PE, Brazil

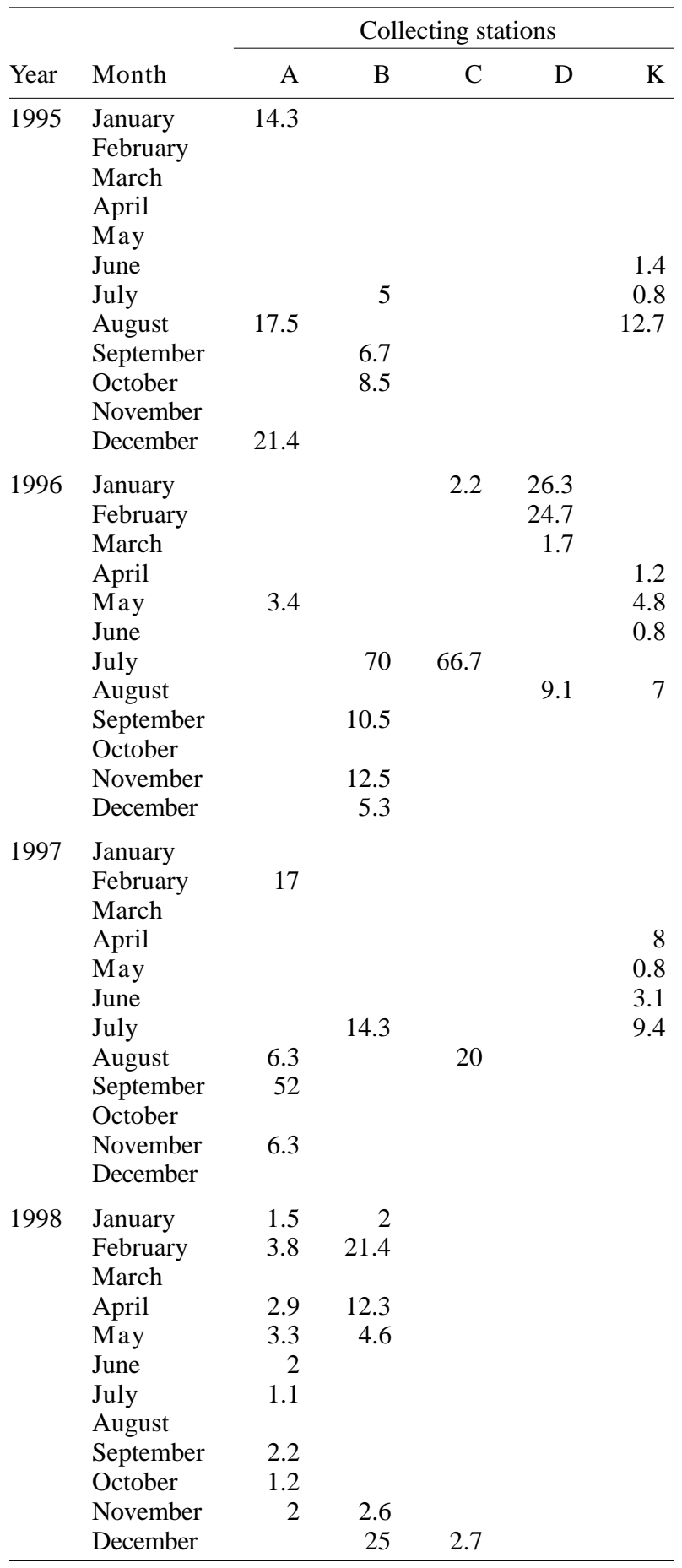

account for the high prevalence of human reinfection (54\% and 84.6\%) in this locality in September 1997 and March 1998 respectively (Favre 1999). In Bom Jesus, on the other hand, the rate of focal infection for B. glabrata, which reached high levels between August and October 1997 $(52 \%)$, was not followed by higher rates of human reinfection (26.2\% and 26.3\%) in September 1997 and March 1998 respectively (Favre 1999). Such a discrepancy can be understood once we consider that in Corte do Camorim 61\% of the population were constantly in contact with transmission foci, compared with only $17 \%$ in Bom Jesus (Favre 1999). Despite the reduced contact with water by the residents of Bom Jesus during the last year of survey (probably due to the implementation of a piping system in 1997), it is possible that the reinfection resulted from the contact with water containing large number of infected snails found near the houses in September 1997.

It is also of interest that the low and high infection rates for B. straminea and B. glabrata respectively did not correspond to the prevalence rates of human infection at the transmission sites. To the contrary, both prevalence and intensity of infection remained higher in Corte do Camorim than in Bom Jesus (Favre 1999). This suggests that in the areas where schistosomiasis is transmitted by $B$. straminea alone, the risk of infection is attributable to frequent contact of the population with snail habitats (Barbosa \& Coelho 1956). This behavioural pattern is probably responsible for the higher human infection rates in the endemic areas where $B$. straminea is the snail host when compared with areas where transmission involves B. glabrata (Lucena 1950, 1963).

It is also possible that in large areas of Northeastern Brazil where $B$. straminea is the only snail host species low rates of natural infection may be compensated by high population density (Rey 1991). However, this argument does not apply to Corte do Camorim, as $B$. straminea at a relatively low abundance was able to maintain high level of human infection. It must be concluded therefore that the relationship between snail abundance, human water contact and human infection rates are very complex and can only be unravelled by further detailed field studies.

\section{TABLE III}

Epidemiological data for schistosomiasis in Corte de Camorim, São Lourenço da Mata and Bom Jesus, Itamaracá, based on a stool survey and a home questionnaire before chemotherapy (March 1995)

\begin{tabular}{lcc}
\hline Variables & Corte do Camorim & Bom Jesus \\
\hline Population & 357 & 141 \\
Prevalence of infection (\%) & 33.5 & 40.3 \\
Geometric mean of & & \\
eggs per gram of feaces (epg) & 48.5 & 48.9 \\
Socio-economic standing & Precarious & Precarious \\
People's contact with water & Intense & Intense \\
Health and hygiene measures & None & None \\
Sanitation measures & None & None \\
Water piping & None & None \\
Species of host snail & Biomphalaria & Biomphalaria \\
& straminea & glabrata \\
\hline
\end{tabular}


B. glabrata in Bom Jesus is a superior intermediate host of S. mansoni than B. straminea in Corte do Camorim. Thus $B$. glabrata snails were found to be infected over a long period and to have higher infection rates than those for $B$. straminea. This view was confirmed by the susceptibility test using local combinations of parasite-snail from Corte do Camorim and Bom Jesus. In this test, $B$. glabrata infection rates were significantly higher than those observed for $B$. straminea, even when the latter was infected with the $S$. mansoni strain from Corte do Camorim.

Other comparative studies on the susceptibility of the snail hosts in the Northeast (Barbosa \& Coelho 1954, Barbosa et al. 1954, Coelho \& Barbosa 1956, Barbosa \& Figueiredo 1970, Barbosa 1975) and in other areas of Brazil (Maia 1984, Paraense \& Corrêa 1989, Souza 1993, Favre et al. 1995) have also revealed that B. straminea is less susceptible to infection. S. mansoni is physiologically better adapted to $B$. glabrata, as the duration of infection is longer and the production of cercariae higher in this species.

It is, however, noteworthy that focal infection of B. straminea in the snail habitats in Corte do Camorim reached remarkably high levels (at least 15 times higher) than those obtained by other authors in Brazil (CunhaNeto 1972, Alvim 1974). In localities within the endemic area of Pernambuco, rates of natural infection of $B$. straminea very seldom exceed $1 \%$, and, in most localities, infection rates are lower than $0.01 \%$ (Barbosa \& Coelho 1956, Paraense \& Corrêa 1989).

The difference in natural infection rates for $B$. straminea in relation to those reported by other authors may be attributable to differences in methodology. Most malacological surveys that aim to assess the natural infection of $B$. straminea are based on one annual sample of high density snail populations over a wide area. This approach may underestimate the real level of infectivity in transmission foci where the only snail host species is B. straminea. The transmission of schistosomiasis in the Northeast of Brazil is focal in nature (Kloetzel \& Schuster 1987) and probably seasonal (Pinotti et al. 1960). As a result, reliable estimates on natural infection of this snail species are only possible by means of monthly or seasonal observations, in previously demarcated sampling sites, so as to avoid underestimation of those breeding places with epidemiological relevance. This more labourintensive approach may yield infection rates that are much higher than those generally obtained for B. straminea using other methods.

Among the field populations subjected to systematic sampling for S. mansoni infection are B. glabrata from St. Lucia (Sturrock 1973), B. alexandrina from Egypt (El Sawy et al. 1989) and B. pfeifferi from Zimbabwe (Woolhouse \& Chandiwana 1989), Ethiopia (Gundersen et al. 1990) and Sudan (Hilali et al. 1995). The information thus gathered about the focality as well as the seasonality of transmission has helped to develop better control strategies in the areas studied.

As regards the areas of the present study the data indicate that continuous, long lasting control measures are required, as practically all water-contact sites harbor host snails during most part of the year. Unfortunately, intensive, repeated application of conventional molluscicide has been shown to be counterproductive in such areas (Barbosa \& Costa 1981, Pieri et al 1995). It is clear that an alternative approach for snail control is needed here, which could involve controlled release formulations of natural products acting continuously against the target snails (Thomas 1995).

\section{TABLE IV}

Prevalence of infection [\% with eggs per gram of faeces (epg) > 0] and prevalence of moderate to heavy infection $(\%$ with epg $>100$ ) in two localities of de endemic area of schistosomiasis in Pernambuco. The surveys marked by asterisks were followed by treatment of the infected persons with oxamniquine

\begin{tabular}{lccrrr}
\hline & \multicolumn{2}{c}{ Corte de Camorim } & & \multicolumn{2}{c}{ Bom Jesus } \\
\cline { 2 - 3 } \cline { 5 - 6 } Survey & \% with epg $>0$ & \% with epg $>100$ & & \% with epg $>0$ & \% with epg $>100$ \\
\hline March 1995* & 33.5 & 8.4 & 40.3 & 17 \\
March 1996 & 25.1 & 17.4 & 14.4 & 5.3 \\
March 1997* & 43.1 & 22.1 & 15.8 & 5 \\
March 1998* & 61.9 & & 20.8 & 0 \\
\hline
\end{tabular}

TABLE V

Results of experimental infection of Biomphalaria straminea from Camorim and B. glabrata from Bom Jesus with local and alotopic strains of Schistosoma mansoni

\begin{tabular}{llcccc}
\hline Snail species & $\begin{array}{l}\text { Origin of } \\
\text { S. mansoni }\end{array}$ & $\begin{array}{c}\text { Number of } \\
\text { exposed snails }\end{array}$ & $\begin{array}{c}\text { Number of } \\
\text { infected snails } \\
\text { shedding cercariae }\end{array}$ & $\begin{array}{c}\text { Number of snails } \\
\text { infected with a different } \\
\text { larval stage of S. mansoni }\end{array}$ & $\begin{array}{c}\% \text { of infected } \\
\text { snails }\end{array}$ \\
\hline B. straminea & Camorim & 250 & 1 & 9 & 4 \\
B. straminea & Bom Jesus & 250 & 0 & 10 & 4 \\
B. glabrata & Bom Jesus & 250 & 116 & 4 & 48 \\
B. glabrata & Camorim & 250 & 33 & 13 & 18.4 \\
\hline
\end{tabular}




\section{TABLE VI}

Average, minimum and maximum values for rainfall, water level, relative abundance and natural infection of Biomphalaria straminea and B. glabrata in the transmission foci of Corte do Camorim and Bom Jesus, respectively, from January 1995 to December 1998, in the three climatic seasons defined by Barbosa (1962)

\begin{tabular}{|c|c|c|c|c|}
\hline & Variable & $\begin{array}{c}\text { Winter } \\
\text { (April-July) }\end{array}$ & $\begin{array}{c}\text { Post-winter } \\
\text { (August-November) }\end{array}$ & $\begin{array}{c}\text { Summer } \\
\text { (December-March) }\end{array}$ \\
\hline \multirow{2}{*}{ 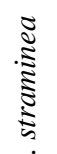 } & Rainfall (mm) & $\begin{array}{c}228.9 \\
(58.8-438.3)\end{array}$ & $\begin{array}{c}61.2 \\
(0-245.8)\end{array}$ & $\begin{array}{c}74.7 \\
(0.9-237.4)\end{array}$ \\
\hline & Level of water in the foci & High & Normal & Low \\
\hline 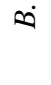 & Relative abundance (snail/person/min) & $\begin{array}{c}1.6 \\
(0-3.9)\end{array}$ & $\begin{array}{c}1.8 \\
(0-3.2)\end{array}$ & $\begin{array}{c}1.9 \\
(0-4.8)\end{array}$ \\
\hline \multirow{4}{*}{ 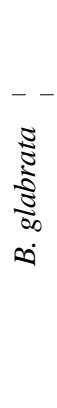 } & $\begin{array}{l}\text { Infection rate }(\%) \\
----------------- \\
\text { Rainfall (mm) }\end{array}$ & $\begin{array}{c}0.5 \\
(0-4.3) \\
------- \\
2788 \\
(104.9-521.8)\end{array}$ & $\begin{array}{c}0.3 \\
(0-1.3) \\
------ \\
78.6 \\
(15.5-277.2)\end{array}$ & $\begin{array}{c}0.3 \\
(0-4.5) \\
-------- \\
89.9 \\
(4.7-220.5)\end{array}$ \\
\hline & Level of water in the foci & High & Normal & Low \\
\hline & Relative abundance (snail/person/min) & $\begin{array}{c}1.8 \\
(0.1-3.9)\end{array}$ & $\begin{array}{c}1.7 \\
(0-7.0)\end{array}$ & $\begin{array}{c}1.2 \\
(0-3.6)\end{array}$ \\
\hline & Infection rate $(\%)$ & $\begin{array}{c}2.9 \\
(0-9.6)\end{array}$ & $\begin{array}{c}6.6 \\
(0-52.0)\end{array}$ & $\begin{array}{c}2.8 \\
(0-13.4)\end{array}$ \\
\hline
\end{tabular}

The introduction of $B$. straminea strains which are resistant to $S$. mansoni infection into habitats of B. glabrata has been sought as a promising biological control measure due to the greater fecundity of the former snail species (Michelson \& Dubois 1979). Field data from the endemic area of schistosomiasis in Northeastern Brazil has indicated that $B$. straminea can competitively displace $B$. glabrata (Barbosa 1987). However, the relatively high rates of natural infection obtained for $B$. straminea in the present study should discourage the introduction of a resistant strain of this species in this area. As pointed out by Sturrock (1995) there is a risk that the initially resistant strain could become more susceptible through hybridization with the local strain.

\section{ACKNOWLEDGMENTS}

To Dr Lygia Corrêa and her technical staff for the important assistance and effort to provide us with snail supplies from the Departament of Malacology, Instituto Oswaldo Cruz. To the technical staff of the Department of Parasitology, Instituto Aggeu Magalhães, for their support in the malacogical and parasitological surveys.

\section{REFERENCES}

Alvim MC 1974. Suscetibilidade de Biomphalaria glabrata e Biomphalaria straminea do Maranhão a uma Cepa Simpátrica de Schistosoma mansoni, MSc Thesis, Universidade Federal de Minas Gerais, Belo Horizonte, 125 pp.

Barbosa CS, Coimbra CEAJ 2000. A construção cultural da esquistossomose em comunidade agrícola de Pernambuco. In RB Barata, R Briceño-Leon (eds), Doenças Endêmicas: Abordagens Sociais, Culturais e Comportamentais, Fiocruz, Rio de Janeiro, p. 47-61.

Barbosa CS, Domingues ALC, Abath FC, Montenegro SML, Guida U, Spinelli V 2001. Epidemia de esquistossomose aguda na praia de Porto de Galinhas, Pernambuco, Brasil. Cad Saú Púb 17: 109-112.

Barbosa CS, Pieri OS, Silva CB, Barbosa FS 2000. Ecoepidemiologia da esquistossomose urbana na ilha de Itamaracá, Estado de Pernambuco. Rev Saúde Pública 34: 337-341.

Barbosa FS 1962. Aspects of the ecology of the intermediate hosts of Schistosoma mansoni interfering with the transmission of bilharziasis in North-Eastern Brazil. Ciba Foundation Symposium on Bilharziasis, Cairo, p. 23-35.

Barbosa FS 1975. Survival and cercarial production of brazilian Biomphalaria glabrata and B. straminea infected with Schistosoma mansoni. J Parasitol 61: 151-152.

Barbosa FS 1987. Competitive displacement of Biomphalaria glabrata by B. straminea. Mem Inst Oswaldo Cruz. 82: 139-141.

Barbosa FS, Coelho MV 1954. Qualidade de vetor dos hospedeiros de Schistosoma mansoni no Nordeste do Brasil. I. Suscetibilidade de Australorbis glabratus e Tropicorbis centreimentralis à infecção por Schistosoma mansoni. Publ Av Inst Aggeu Magalhães 3: 55-62.

Barbosa FS, Coelho MV 1956. Alguns aspectos epidemiológicos relacionados com a transmissão da esquistossomose em Pernambuco, Brasil. Publ Av Inst Aggeu Magalhães 5: 3147.

Barbosa FS, Costa DPP 1981. A long-term schistosomiasis control project with molluscicide in a rural area of Brazil. Ann Trop Med Parasitol 75: 41-52.

Barbosa FS, Figueiredo T 1970. Suscetibility of the snail intermediate hosts of schistosomiasis from northeastern Brazil to the infection with Schistosoma mansoni. Rev Inst Med Trop São Paulo 12: 198-206.

Barbosa FS, Coelho MV, Dobbin JE 1954. Qualidade de vetor dos hospedeiros de Schistosoma mansoni no Nordeste do Brasil. II. Duração da infestação e eliminação de cercárias em Australorbis glabratus. Publ Av Inst Aggeu Magalhães 7: 79-92. 
Coelho MV, Barbosa FS 1956. Qualidades de vetor dos hospedeiros de Schistosoma mansoni no Nordeste do Brasil. III. Duração da infestação e eliminação de cercárias em Tropicorbis centimentralis. Publ Av Inst Aggeu Magalhães 5: 21-29.

Cunha-Neto AG 1972. Biomphalaria straminea em Porto Alegre, Rio Grande do Sul, Brasil. Atas Soc Bio RJ 15: 151.

Dazo BC, Sudomo M, Hardjawidjaja L, Joesoef A, Bardoji A 1976. Control of Schistosoma japonicum infection in Lindu Valley, Central Sulawesi, Indonésia. Southeast Asian J Trop Med Public Health 7: 330-340.

El Sawy MF, Duncan J, Amer S, El Ruweini H, Brown N 1989. The molluscicidal properties of Ambrosia maritima L. (Compositae). 4. Temporal and spatial distribution of Biomphalaria alexandrina in Egyptian village irrigation systems with reference to schistosomiasis transmission control. Trop Med Parasitol 40: 103-106.

Favre TC 1999. Impacto da Quimioterapia com Oxamniquine sobre a Infecção por Schistosoma mansoni em Duas Localidades da Zona Litoral-Mata de Pernambuco, $\mathrm{PhD}$ Thesis, Fundação Oswaldo Cruz, Rio de Janeiro, 148 pp.

Favre TC, Bógea THP, Rotenberg L, Silva HS, Pieri OS 1995. Cercarial emergence of Schistosoma mansoni from Biomphalaria glabrata and Biomphalaria straminea. Mem Inst Oswaldo Cruz 90: 565-567.

Gundersen SG, Birrie H, Torvik HP, Scherbaum H 1990. Control of Schistosoma mansoni in the Blue Nile Valley of western Ethiopia by mass chemotherapy and focal snail control: a primary health care experience. Trans $R$ Soc Trop Med Hyg 84: 819-825.

Hilali AHM, Madsen H, Daffalla AA, Wassila M, Christensen NO 1995. Infection and transmission pattern of Schistosoma mansoni in the Managil irrigation scheme, Sudan. Ann Trop Med Parasitol 89: 279-286.

Katz N, Chaves A, Pellegrino J 1972. A simple device for quantitative stool thick-smear technique in schistosomiasis mansoni. Rev Inst Med Trop São Paulo 14: 397-400.

Kloetzel K, Schuster NH 1987. Repeated mass treatment of schistosomiasis mansoni: experience in hyperendemic areas of Brazil. I. Parasitogical effects and morbidity. Trans $R$ Soc Trop Med Hyg 81: 365-370.

Lucena DT 1950. Epidemiologia da esquistossomose mansoni. An Soc Pernambuco 2: 12-28.

Lucena DT 1963. Planorbídeos transmissores da esquistossomose no nordeste do Brasil. Rev Bras Malariol Doen Trop 15: 13-26.

Maia MA 1984. Estudo da suscetibilidade de molusco planorbídeo, Biomphalaria straminea (Dunker, 1848), de Goiânia, GO, à infecção por cepas de Schistosoma mansoni Sambon, 1907. Rev Pat Trop 12: 113-166.

Michelson EH, Dubois L 1979. Competitive interaction be- tween two snail hosts of Schistosoma mansoni: laboratory studies on Biomphalaria glabrata and Biomphalaria straminea. Rev Inst Med Trop São Paulo 21: 246-253.

Moza PG, Pieri OS, Barbosa CS, Rey L 1998. Fatores sóciodemográficos e comportamentais relacionados à esquistossomose em uma agrovila da zona canavierira de Pernambuco, Brasil. Cad Saú Públ 14: 107-115.

Olivier LJ 1973. Techniques, statistical methods and recording forms: A. techniques. In N Ansari, Epidemiology and Control of Schistsosomiasis, Karger, Basel and University Park Press, Baltimore, p. 620-704

Olivier LJ, Scheinderman M 1956. A method for estimating the density of aquatic snail population. Exp Parasitol 5: 109117.

Paraense WL, Corrêa LR 1989. A potential vector of Schistosoma mansoni in Uruguay. Mem Inst Oswaldo Cruz 84: 281-288.

Pieri OS, Barbosa CS, Moza PG 1998. Schistosomiasis control based on repeated chemotherapy in a rural village of the sugar-cane zone in Northeast Brazil. Mem Inst Oswaldo Cruz 93: 259-264.

Pieri OS, Gonçalves JF, Sarquis O 1995. Repeated focal mollusciciding for snail control in a sugar-cane area of northeast Brazil. Mem Inst Oswaldo Cruz 90: 535-536.

Pinotti M, Rey L, Aragão MB, Cunha AG 1960. Epidemiologia da esquistossomose e variação periódica das populações malacológicas, em Pernambuco, Brasil. Rev Inst Med Trop São Paulo 2: 183-188.

Rey L 1991. Parasitologia, Guanabara-Koogan, Rio de Janeiro, $731 \mathrm{pp}$.

Sokal RS, Rohlf FJ 1995. Biometry: The Principles and Pratice of Statistics in Biological Research, WH Freeman and Co., New York, 887 pp.

Souza CP 1993. Schistosoma mansoni: Aspectos Quantitativos da Interação Hospedeiro-Parasito e Desenvolvimento em Biomphalaria glabrata, Biomphalaria tenagophila e Biomphalaria straminea, MSc Thesis, Universidade de Minas Gerais, Belo Horizonte, 279 pp.

Sturrock RF 1973. Field studies on the transmission of Schistosoma mansoni and on the bionomics of its intermediate host, Biomphalaria glabrata, on St. Lucia, West Indies. IJ Parasitol 3: 175-194.

Sturrock RF 1995. Current concepts of snail control. Mem Inst Oswaldo Cruz 90: 241-248.

Thomas JD 1995. The snail hosts of schistosomiasis: some evolutionary and ecological perspectives in relation to control. Mem Inst Oswaldo Cruz 90: 195-204.

Woolhouse MEJ, Chandiwana SK 1989. Spatial and temporal heterogeneity in the population dynamics of Bulinus globosus and Biomphalaria pfeifferi and the epidemiology of their infection with schistosomes. Parasitology 98: 21-34. 
476 Natural Infection of Biomphalaria spp. - Tereza C Favre et al. 